\title{
Populist politics of representation and foreign policy: evidence from Poland
}

\author{
David Cadier ${ }^{1,2}$ (ID
}

Accepted: 30 August 2021 / Published online: 14 September 2021

(c) The Author(s), under exclusive licence to Springer Nature Limited 2021

\begin{abstract}
This article characterizes and analyses variations in Poland's foreign policy under the Law and Justice (PiS) government with a view to shed light on the distinctive influence of populism. I argue that this influence has mainly to do with the 'politics of representation', understood both in the sense of meaning production and of theatrical performance. Building on the discursive and stylistic approaches to populism as well as on the post-structuralist literature in Foreign Policy Analysis, this article conceptualizes populism as a set of representational practices in domestic politics that spill over, and affect, foreign policy. By promoting distinct representations of Self and Other in international affairs and by investing foreign policy making as a site to perform a rupture with technocratic elites, populist practices contribute to enable or constrain certain policy choices and mode of diplomatic actions. In Poland, this has translated into a securitization of the EU, a partial de-Europeanization of the national interest and a re-shuffling of partnership prioritizations, as well as in disruptive and 'undiplomatic' comments on the part of the PiS foreign policy executive.
\end{abstract}

Keywords Populism $\cdot$ Foreign Policy $\cdot$ Poland $\cdot$ Diplomacy $\cdot$ Discourse $\cdot$ EU

Since the populist rightwing party Law and Justice (Prawo $i$ SprawiedliwośćPiS) came to power in 2015, Poland's foreign policy has exhibited some discernable and, at times, counter-intuitive alterations. While previous Polish governments had mainly represented the European Union (EU) as an opportunity for their country, the PiS government has, instead, often characterized it as a risk or threat, to the extent of sometimes likening it to the USSR. While Poland has long been, and remains, one of the few member states advocating EU membership for Ukraine, the

David Cadier

david.cadier@sciencespo.fr

1 Department of International Relations and International Organization, University of Groningen, PO box 716, 9700 AS Groningen, Netherlands

2 LSE IDEAS, London School of Economics, London, UK 
PiS foreign minister threatened to block its (hypothetical) future accession in the context of a feud over historical memory. ${ }^{1}$ While Warsaw has constantly perceived and relentlessly denounced Russia as posing a threat to its national security, the PiS defence minister ended up acting, albeit unwillingly, as a relay of Russian disinformation when peddling in the Polish Parliament a conspiracy theory originating from pro-Kremlin websites. ${ }^{2}$ Finally, in line with Poland's traditional atlanticism, the PiS government strived and largely succeeded to establish privileged ties with the Trump administration, but at some point the White House imposed a temporary ban on Presidential-level meetings with Warsaw in protest against PiS so-called 'Holocaust law' on historical memory. ${ }^{3}$

To be sure, these changes should not be reified, amalgamated or exaggerated, but need to be methodically analysed and contextualized, especially as some amount more to unintended or uncontrolled externalities of PiS domestic political practice than to purposive foreign policy behaviour. In any case, they immediately prompt the following questions: What is the nature and extent of the changes imprinted in Polish foreign policy by the PiS executive since 2015? To what extent can these changes be attributed to its populist orientation? More generally, how does populism influence foreign policy choices and foreign policy implementation?

To address this question, this article traces and unpacks variations in Polish foreign policy under the PiS government. I argue that the influence of populism has mainly to do with what some scholars have termed the "politics of representation" (Milliken 1999, 226), understood here both in the sense of meaning production and theatrical performance. In itself, populism does not translate into programmatic ideas, substantive preferences, or clearly defined intentions in foreign policy, but rather into a distinct manner or logic in articulating and representing foreign policy content (which can itself be informed by the party's thick ideology or the country's security imaginary). At the same time, however, these representational practices are performative and have a structural effect on foreign policy outcomes: by promoting distinct representations of Self and Other in international affairs and by investing foreign policy making as a site to perform a rupture with technocratic elites, populism enables certain policy choices and modes of policy implementation while disabling others.

The manners in which foreign policy outputs and processes are impacted when populist actors are in office remains underexplored (see Introduction to this Special Issue). Although the generalization potential of this study is necessarily circumvented to that of a single case analysis, the case itself, and the conceptual approach chosen, allows for the article to make both an empirical and theoretical contribution

\footnotetext{
1 'Waszczykowski dla 'wSieci' o stosunkach polsko-ukraińskich: Nasz przekaz jest bardzo jasny: z Banderą do Europy nie wejdziecie', wPolityce.pl, 3/07/2017, https://wpolityce.pl/polityka/347083-waszc zykowski-dla-wsieci-o-stosunkach-polsko-ukrainskich-nasz-przekaz-jest-bardzo-jasny-z-bandera-doeuropy-nie-wejdziecie.

2 'Macierewicz dał się nabrać prokremlowskim portalom? Twierdzi, że Egipt oddał Rosji mistrale z 1 dolara', Gazeta.pl, 21/10/2016.

3 'Trump and Poland: From Love to Hate in Under Nine Months', Daily Beast, 03/09/2018, https://www. thedailybeast.com/trump-and-poland-from-love-to-hate-in-under-nine-months.
} 
in that sense. As PiS has been in control of both the Parliament and the Presidency since October 2015, it has had the means and time to potentially shape the country's foreign policy and Poland can thus be considered as a 'most likely' case when it comes to the influence of populism on foreign policy. Yet, available empirical accounts of the PiS government's foreign policy have mainly focused on the party's thick ideology (Varga and Buzogány 2020; Zwolski 2017) or on external geopolitical factors (Lanoszka 2020) rather than on populism as such. In addition, the Polish case deviates from some of the common expectations advanced in the literature on the topic, such as the increased personalization of foreign policy or the advent of a more pro-Russian orientation under populist leadership. As such, it invites additional theory developments. Finally, most of the works interested in investigating the impact of populism on foreign policy have approached it as a thin ideology (Plagemann and Destradi 2019; Wehner and Thies 2020), while those conceptualizing populism as a discourse applied to foreign policy (Wojczewski 2019b) generally stop short of considering the implication in terms of policy outcomes. By advancing new theoretical expectations based on the discursive and stylistic approaches to populism and the post-structuralist literature, and by integrating them into a non-positivist explanation of foreign policy, this article aims to contribute to bridge this gap, to address calls for eclecticism in exploring the relationship between populism and foreign policy (Chryssogelos 2017), and to advance more generally the interdisciplinary dialogue between Comparative Politics and Foreign Policy Analysis.

The article begins with presenting the conceptual framework guiding the analysis. Subsequently, the methods employed and data collected for the study, as well as some elements of context about PiS and Polish foreign policy, are presented. Then, the core of the article contrasts the foreign policy of the PiS executive with that of previous Polish governments with a view to characterize the distinctive influence of populism. The focus is notably placed on policies towards the USA and Russia, on policies towards the EU and fellow EU member states, and on diplomatic practice.

\section{Conceptual framework: populism and foreign policy}

Available studies on the relationship between populism and foreign policy generally rely on elaborate conceptualizations of populism yet rarely specify the pathways by which it might influence foreign policy. The approach chosen in this article is sceptical about the possibility of instituting populism as an independent causal variable in a rigid positivist framework. Rather than as ideas having "some independent causal power with measurable effects" (i.e. as per the ideational approach) (Hawkins et al. $2018,6)$, this article understands populism as a set of representational practices and relies on discourse analysis to study how they are reproduced in, and affecting, foreign policy. As theorized by post-structuralist FPA scholars, "adopting one mode of representations over another" has, indeed, "manifest political consequences" for foreign policy (Campbell 1998, 8). The discursive approach does not necessarily imply to limit the analysis to how foreign policy is used as a terrain for populist practices, but can also be mobilized to study these 'consequences' (though without offering a causal explanation in the positivist sense of the term). Discourse analysis can indeed 
shed light on the "bandwidth of possible outcomes" in foreign policy (Neumann 2008,62 ) and on "how and on which basis specific policies came to be adopted" (Diez 2014, 324). This requires, however, to rely on a dynamic (rather than linear) understanding of foreign policy outcomes, one that integrates the co-constitution of practices and structures and how

decision-makers not only make choices but are also intimately involved - both intentionally and unintentionally - in the collective production and reproduction of social structures and how the consequences of this process, in turn, both constrain and enable their subsequent actions (Carlsnaes 1993, 13).

The core contention of this article is that, although not necessarily concerned with foreign affairs in the first place, populist practices in domestic politics contribute to shape the social structures in which foreign policy is formulated, debated, and implemented. Combined with that of post-structuralist FPA, insights from the discursive and stylistic approaches to populism allow specifying the modalities of this influence on foreign policy choices and implementation.

Following Ernersto Laclau, populism can be conceptualized as a logic of political articulation (or discourse) that promotes certain arrangements of meaning and representations of identity. Rather than merely reflecting them as pre-existing social categories, the populist discourse is actively involved in constituting the 'people' and 'elite' and in constructing their political subjectivity by establishing a system of relation between terms (Laclau 2005a, b; see also: Stavrakakis and Katsambekis 2014). In this understanding, what defines populism-and thus, one can infer, the modalities of its effects on policies-is not political or ideological content, but rather the manner in which this content is articulated (Laclau 2005b, 33). The populist logic of articulation can be projected onto foreign policy in two ways. On the one hand, populist actors are likely to convoke subjects and objects of international politics in their articulatory practice of othering domestic elites and interpellating the people as 'underdog' (see: Wojczewski 2019a, b). As such, populist actors can be expected to (re)produce distinct representations of Self and Other in international relations as well as, relatedly, of the State, of its interests, and of foreign policy problems and solutions. On the other hand, populist actors are likely to displace and apply the populist mode of discursive articulation to the foreign policy realm-especially when, after being elected into office, they have themselves somehow become the power or establishment and need new ways to interpellate 'the people'. Concretely, the State is likely to be represented as an 'underdog' in a given international or regional order and certain foreign powers othered as the 'elite' or 'establishment' frustrating its legitimate national demands. For instance, in the historical discourse of the PiS government, the categories of victims and perpetrators have been totalized and essentialized and Poland is represented as the 'Christ of European nations' (Cadier and Szulecki 2020).

This projection of the populist logic of articulation is, in turn, likely to have a constitutive and structural influence on foreign policy. On the one hand, through their articulatory practice, political actors promote particular set of meanings and, as such, create certain interpretative dispositions and representations of foreign policy issues on which actions, decisions and choices are then based (Weldes 1999, 
10-16). In that sense, populist actors are likely to contribute to shape the structures of meaning in which foreign policy is debated, formulated, and implementedespecially when they are in office and control the means of public communication. On the other hand, policy-makers are not only shaping structures of meaning, but also find themselves constrained by them in that they delimit the realm of legitimate and reasonable policy and, as such, enable certain policy choices while disabling others (Milliken 1999, 240; Diez 2014, 320). Policy-makers constantly need, indeed, to articulate their policies with the State's vision of itself, and the fate of a policy option is thus conditioned on its 'combinability' with prevailing representations of identity (Hansen 2006, 18). For instance, Zaslove and Verbeek (2015) have shown that what had conditioned most the foreign policy decisions of the Lega when the party was in government in Italy was the possibility of articulating the policy option at stake with their conception (or representation) of 'the people'.

To the extent that "discourses manifest themselves in both linguistic and nonlinguistic practices" (Weldes and Laffey 2004, 28), the insights of the discursive approach can be complemented by the scholarship conceptualizing populism as a performative political style (Moffitt 2017). The reliance on, and incarnation of, the populist political style to mark a distance with the 'elite' can be expected to affect the conduct and implementation of foreign policy. In particular, the "championing of "common sense' against the bureaucrats" and the "denial of expert knowledge" (Moffitt 2017, 52) means that populist governments are more likely to sideline Ministries of Foreign Affairs (MFAs) and professional diplomats. In addition, populist actors' ostentatious "disregard for 'appropriate' ways of acting in the political realm" and "simplification of the terms of political debate" (ibid. 52-53) means that they are more likely to indulge in 'undiplomatic diplomacy' or conspiracy theories (Cadier, 2019). ${ }^{4}$ This proclivity has, for instance, been documented empirically in the context of the Global South by Sandra Destradi and Johannes Plagemann (2019, 725-27). Obviously, the first proclivity feeds into the second, as professional diplomats and MFAs generally act as gate-keepers of what is perceived as 'appropriate' diplomatic practice. For instance, in the USA, Donald Trump's "weakening of foreign policy bureaucracies" resulted from a "mixture of intention and incompetence" (Drezner 2019, 723, 728) and, in that sense, the stylistic approach allows to capture both intended and unintended effects of populism on foreign policy.

In summary, the reliance on populism as a set of representational practices can be expected to have constitutive significance for how foreign policy is formulated, debated, and implemented. While in power, populist actors are likely to promote distinct representations of Self and Other in international affairs and to use diplomacy as a way to perform a rupture with technocratic elites. This is, in turn, likely to condition, constrain, or enable, foreign policy choices and diplomatic actions.

\footnotetext{
4 This term is proposed based on the acceptation of diplomacy as "representing the instinct for caution and sophistication" (Hill 2015, 158).
} 


\section{Data, methods, and contexts}

These propositions are illustrated with reference to the case of Poland, where the populist right-wing party Law and Justice is in control of the Executive branch after having won in 2015, and again in 2019/2020, both the Presidential and legislative elections. In terms of empirical data, the article builds on the analysis of official documents, speeches, and public statements from the PiS foreign policy executive (i.e. Prime Minister, President, and Ministers with relevant portfolio such as foreign affairs, defence or trade) as well as on semi-structured interviews with Polish diplomats, governmental advisers, and experts, including some affiliated to PiS. ${ }^{5}$ From a methodological point of view, I rely on a 'before-after' research design-that is on the division of a single longitudinal case into two sub-cases (George and Bennett 2005, 178-79)_adapted to discourse analysis. The 'before-after' division is materialized by the delineation between the non-populist government of the Civic Platform (Platforma Obywatelska-PO) (2007-2015) and the populist government of the PiS (2015-present). Consistent with the theoretical model presented above, I expect the PiS government to promote distinct representations of identity and, relatedly, distinct policy-identity constructions in foreign policy. At the same time, these constructions and their stability, as well as the deliberation of identity and policy, are necessarily contingent on the broader social, political, and geopolitical context in which they are situated (Hansen 2006, 26). These elements of contexts are briefly presented below so as to pave the ground for the empirical analysis.

The political DNA of PiS can be described as conservative, nativist, and illiberal. Conservatism clearly constitutes the core political ideology informing politics and policy-making under PiS (Dąbrowska 2018). Rather than as rejecting any form of change, it accepts and calls for a specific kind, namely one that "aims at re-establishing the natural order which at the same time is a moral one" (ibid. 109). The 'Good Change' was, in fact, one of the party's electoral slogans. On the cultural front, this has led PiS policy-makers to insist on the notion of "normality', praise traditional values such as the family and Christianity, and denounce multiculturalism, same sex marriages and what they castigate as 'LGBT and gender ideology'. On the political front, PiS conservatism is mainly constructed as an alternative to technocratic liberalism and how it imposed itself in Poland during the year of the post-communist transition. Since the 1990s, the incrimination of a collusion - and continuity-between communist and post-communist liberal elites has been at the heart of Kaczynski and other PiS ideologues' political message, leading them to equate, and equally oppose, communism and liberalism (see, for instance, Legutko 2018). The denunciation of post-communist liberal elites and, relatedly, of the West as a vector of technocratic liberalism found resonance among an important share of the population due to the resentment fuelled by the transition period, the humiliation of political imitation, and the denial of any political alternatives (Zielonka and Rupnik 2020; Krastev and Holmes 2019).

\footnotetext{
5 A significant amount of this empirical data was notably collected on the occasion of an eight-month fieldwork in Warsaw in 2017.
} 
While the discrepancy between a "rhetorical commitment to liberal-democratic pluralism" and a "benignly neglectful monism in the form of technocratic government" (Bill and Stanley 2020, 379) provided a favourable terrain for an anti-liberal backlash, PiS mobilized these grievances in the sense of its own ideological and political agenda. As potently demonstrated by Stanley Bill and Ben Stanley (ibid. 378), PiS militated for a re-politicization of public policy in reaction to technocratic liberalism's monism and metapolitics of moderation, but then reintroduced a new form of monism characterized by "nativist cultural policies" and the "colonisation of the political-institutional infrastructure". On the one hand, as has been the case elsewhere in Central Europe, the traditional neighbourhating nationalism has largely transmuted into a civilizationist anti-immigrant platform (Enyedi 2020). On the other hand, the desire to replace a (pluralist) society by an (homogeneous) nation and the belief in a strong state led PiS policymakers to undermine core principles of procedural democracy, notably by putting the independence of the judiciary into question and by turning public media into a mouthpiece for its political agenda. Kaczinski has, in fact, explicitly voiced its admiration for the illiberal regime and policies of Viktor Orban and Recep Tayyip Erdogan (Balcer et al. 2016).

In light of the country's geo-strategic exposure, anxiety-inducing past, and prevailing security imaginary, geopolitical factors have generally been regarded as most influential in shaping the country's foreign policy orientations (Zając 2017, 2-5; Zięba 2020, 15-17) and this can be expected to continue under the PiS government. Therefore, to avoid potential omitted variable bias, the article will first seek to verify that the variations noted in Poland's foreign policy under the PiS government cannot be correlated with alterations in external conditions (e.g. in US or Russia's policy behaviour, in power distribution at the EU level, etc.). The analytical focus remains, however, on populism. While PiS (thick) political ideology informs the government's foreign policy preferences and while external geopolitical conditions mediate its foreign policy choices, these preferences and choices are articulated, represented, and performed through the logic and practices of populism, and this has in turn implications for the formulation and implementation of Polish foreign policy.

\section{Continuity and change in Poland's foreign policy: accounting for the influence of populism}

Three "basic tenets" can traditionally be identified in Polish foreign policy: strengthening bilateral relations with Washington and NATO's collective security mechanisms; deterrence and containment of Russia; and support to Poland's European integration and to EU enlargement. As noted by Kerry Longhurst $(2013,371)$, these priorities have been constant but the "balance, emphasis and relationship between these tenets have [at times] been reconfigured". Such reconfiguration very much happened under the PiS government, with the first tenet being prioritized and the third one downgraded. 


\section{Policies towards the USA and Russia: between status quo and adjustment change}

Since it took office, the PiS government has clearly prioritized bilateral strategic ties with the USA and has sought to position Poland as Washington's best ally in Europe-or, in the words of PiS Deputy Foreign Minister Bartosz Cichocki, as a kind of "substitute for the UK" (cited in: Buras and Janning 2018). This "America First' policy notably translated into the proposal to host and fund a US military base outside of NATO structures ('Fort Trump') (Taylor 2018; Ministry of Defense of the Republic of Poland 2018) and in the channelling, inside the EU, of the Trump administration's diplomatic priorities (e.g. on China), though without going as far as adopting positions that would go against long-established EU consensus (e.g. on Iran or Israel). Rather than to a change of direction, however, this conspicuous Atlanticist orientation corresponds to an upward modulation of a pre-existing policy ('adjustment change') — and one that can be correlated with variations in external conditions. To a large extent, Poland has returned to the strategy and positioning that it had pursued under the Bush administration-a time where Poland was sometime described as a 'Trojan Horse' of the USA in Europe (Osica 2004). The securing of American military deployment on the national territory has been, in fact, one of its core foreign policy priorities since 1989. The US policy of the PiS government does contrast with the 'qualified Atlanticism' (i.e. less automatic and less exclusive) of the PO government, but this stance was itself largely a function of external conditions (namely Obama's pivot policy and negative feedback from Poland's Iraq policy) and was, in fact, abandoned towards the end of the PO's mandate when these conditions changed significantly (namely following Russia's military intervention in Ukraine). In the same manner, the PiS government's US policy can largely be accounted for with reference to the constraints and opportunities emanating from Poland's external environment. The attempt to forge a closer bilateral relationship with Washington was made possible by the Trump's administration own transactional approach to security and by its desire to use Poland and Hungary as wedges in European debates. It was also made necessary by the PiS government's own isolation in Europe (see below). To be sure, their shared populist radical right ideological outlook might have facilitated the interactions between the PiS government and Trump's White House. Yet, this ideological proximity did not prevent US authorities to criticize the PiS government on the reform of its judicial system, the so-called 'Holocaust law' or LGBT rights. In addition, the rather more favourable disposition towards Republican presidents (and Donald Trump in particular) has not been confined to PiS, but shared by a segment of the public opinion (Pew Research Centre 2016) and has been a flong-standing eature of the country's foreign policy tradition. In other words, a non-populist government would have been equally likely to prioritize strategic ties with Washington and pursue initiatives like the Fort Trump proposal (for a similar assessment, see: Lanoszka 2020), though probably less at the expense of its policies in Europe and, arguably, with a different packaging and delivery.

Comparable dynamics are observable, and similar conclusions can be drawn, with regard to Poland's policies towards Russia. The PiS government has adopted, overall, a slightly more confrontational and less compromising posture towards 
Moscow (Sus 2018), but this stance amounts more to the continuation of a preexisting foreign policy orientation than to a change of direction. It undoubtedly contrasts with the rapprochement attempted by the PO government in 2010, but this short-lived initiative was itself a product of the Tusk executive's desire to consolidate Poland's clout inside the EU and was facilitated by specific external conditions (namely Russia's own behaviour and the parallel rapprochements attempted both by the EU and by the Obama administration). In fact, considering that these conditions have severely deteriorated and that while in the opposition Jaroslaw Kaczynski had relentlessly accused Russia of having perpetrated the 2010 Smolensk crash that cost the life of his twin brother, one could have expected for the PiS government's foreign policy discourse to be even more targeted and vehement on Russia, as the nation's perennial and overarching enemy. Instead, as discussed below, the PiS has often articulated the country's identity against Germany.

In summary, when it comes to policies towards the USA and Russia, the PiS government has, more than anything else, been claiming, continuing, or returning to Polish foreign policy tradition. Some adjustment changes were noted, but they could be correlated with variations in external conditions. In other words, the populist orientation (or for that matter the thick ideology) of the PiS government has had little influence on its policies towards the USA and Russia. In fact, its pro-American and anti-Russian attitude is contradictory to what is generally expected from, and common to many, populist parties in Europe, which confirms that in itself populism does not translate into a specific, distinct, and cohesive set of foreign policy preferences.

\section{Policies in and vis a- vis the EU: opposing, and withdrawing from, the EU mainstream?}

Several analysts converge in their assessment that the PiS government has somehow "departed from"- or even "broken with"-Poland's "traditional pro-EU orientation” (Zwolski 2017, 171; Kuźniar 2016, 11). The nature and magnitude of the change incarnated by the PiS government's European policy ought, however, to be qualified as methodically as possible, since this policy has not been free of contradictions and has, at times, been distorted in Polish and international media. Two general patterns of change can be identified.

First, the PiS government has brought upon a shift in the representation of the EU in public and policy discourse. Whereas traditionally previous Polish governments had mainly characterized the EU as an opportunity, the PiS leadership has often depicted it as risk or threat (Balcer et al. 2016, 2). This clearly transpires, for instance, from the qualitative analysis of the yearly 'Addresses by the Minister of Foreign Affairs' presenting the government's foreign policy priorities in Parliament: since PiS coming to power in 2015 and for the first time in Poland's post-communist history, the number of negative characterizations of the EU in these addresses has been comparable (or even superior in 2016) to the number of positive ones (Zuba 2020). This has also been salient in PiS policy-makers' domestic statements and declarations, where the EU is denounced as a threat for its encroaching on Poland's sovereignty and traditional values. In this context, President Duda has regularly 
established parallels between the EU and the USSR, while foreign minister Waszczykowski has spoken of the need to "introduce a negative policy" towards the EU. ${ }^{6}$

This negative characterization of the EU has not, however, translated into equally radical policy decisions. For instance, contrary to several other European populist rightwing parties, the PiS leadership never came close to advocating Poland's exit from the EU. Instead, along the lines of what could be expected from the reliance on populism as a political practice, the opposition to the EU has been performed through symbolic gestures (such as the removal of the EU flag from Prime Minister's Szydło weekly press briefing ${ }^{7}$ ) and has manifested itself in rhetorical contortions (with the PiS government voicing declarative support for the idea of European integration while at the same time denouncing the 'ever closer Union' clause in EU treaties). The PiS government's negative disposition towards the EU is largely grounded in its thick ideology, whereby the EU is perceived as vector of cultural liberalism, supra-nationalism, and cosmopolitanism and as hampering the realization of the party's transformational conservative agenda. But the representation of the EU as a 'corrupt elite' to mobilize the 'pure people' (Csehi and Zgut 2021) reflects the populist logic of articulation and contributes, in turn, to re-define the meaning of Europe in Polish foreign policy discourse.

Second, changes are also notable in the representation of Poland's position, role, and aspirations inside the EU. Since 1989 and as originally conceptualized by the first post-communist foreign minister Krzysztof Skubiszewski, the aim of strengthening Poland's role in the European core had constituted a key element in the country's foreign policy tradition (Kuźniar 2016, 5; Szczerbiak 2012). In particular, the previous PO government had made of enhancing Poland's clout inside the EU its cardinal foreign policy objective: it regularly called for a stronger Poland in a stronger Europe and advocated greater economic integration and additional power transfers to EU institutions (see, for instance, Sikorski 2011). By contrast, as expressed by an advisor to foreign minister Waszczykowski, the PiS executive has been critical of the PO's government's "desire to fit with the EU mainstream" and has rejected the idea that "Poland should speak with one voice with other member states", since both convey the image of a country "not able to act by itself". ${ }^{8}$ In fact, in domestic political discourses, the PiS leader Jaroslaw Kaczynski has more often placed the emphasis on preventing Poland from becoming a "colony" of the EU (cited in: Csehi and Zgut 2021, 9) than on establishing it as a leader inside the bloc. The PiS government's temptation to "withdraw from the mainstream of European politics" (Zwolski 2017, 175) - and the attempt to set up an alternative bloc inside the EU (see below)—reflects the 'anti-mainstream' positioning of populism and proceeds, more profoundly, from its structural logic of articulation representing

\footnotetext{
6 'Polish President Duda likens EU membership to past occupations', DW.com, 15 March 2018, https:// www.dw.com/en/polish-president-duda-likens-eu-membership-to-past-occupations/a-42981160; 'Waszczykowski: "Musimy drastycznie obniżyć poziom zaufania wobec Unii"”, wPolityce.pl, 12 March 2017, https://wpolityce.pl/polityka/331123-podwojne-standardy-w-ue-waszczykowski-musimy-drastycznieobnizyc-poziom-zaufania-wobec-unii-zaczac-prowadzic-takze-polityke-negatywna.

7 'Poland removes EU flag in Brussels snub', Financial Times, 24 November 2015.

${ }^{8}$ Interview with an adviser to the Polish Foreign Minister, Warsaw, 25 October 2017.
} 
the Self as an underdog in a down-up political antagonism. In that sense, populist discourse serves as a template for expressing long-standing grievances about unequal and exploitative centre-periphery relations in Europe (Zarycki 2000) and for articulating, in that context, a counter-hegemonic strategy rejecting normative conformity with the West (Kazharski 2018).

The way the national subject is represented in relation to the EU has, in turn, constitutive significance for the conduct of foreign policy (Larsen 2009). The PiS government performative intent of 'taking back control' and withdrawing from (or opposing) the EU core has been reflected in its posture at the EU level, where it has adopted an "uncompromising", "confrontational" and "defensive" stance (Balcer et al. 2017, 31, 35). More specifically, the PiS government has refused to welcome refugees as per the quotas agreed at the European Council, abandoned the project of becoming a core member of the European intergovernmental military force 'Eurocorps' and blocked, for a time, the reform of the EU's Emissions Trading System (ibid. 22-31). More recently, it vetoed or opposed the adoption of the coronavirus recovery plan, of a text on fundamental rights in the context of artificial intelligence, and of an Action Plan elevating gender equality as an objective of EU foreign policy (on the last two initiatives, the PiS government notably took issue with the notion of 'gender equality' ${ }^{9}$ ). While the first set of decisions are in line with previous directions in Polish foreign policy, the second set appear specifically link to the PiS government and its conservative and illiberal agenda (or thick ideology). At the same time, the manner in which these positions were projected at the EU level reflects a structural reluctance towards consensus-building and compromise-seeking, which can be explained by the PiS government's reliance on populist stylistic and discursive practices. Its approach notably contrasts with the previous government's proclivity towards Europeanizing Polish foreign policy and its ability to "play the Brussels game" in uploading its initiatives (such as the Eastern Partnership) at the EU level (Pomorska 2012).

In sum, the PiS government's foreign policy has been characterized by a distinct securitization of the EU and a partial de-Europeanization of the Polish national interest in policy discourse, although the country's EU membership has not been put into question. Contrary to policies towards the USA or Russia, its European policies appear above all informed and shaped by its domestic political agenda and more specifically by its thick ideology and its reliance on populist practices.

\section{Policies towards EU member states: shifting alliance prioritizations in Europe?}

Under the PiS government, the most salient change of direction in Poland's foreign policy has undeniably pertained to Germany. While the PO had made of the partnership with Berlin the piecemeal of its European policies-with the then foreign minister famously declaring that Poland was now "fearing German power less than

\footnotetext{
9 See: https://www.euractiv.com/section/digital/news/poland-rejects-presidency-conclusions-on-artif icial-intelligence-rights/ https://www.politico.eu/article/eus-gender-equality-push-for-external-relationsfaces-trouble-from-the-inside/.
} 
German inactivity" (Sikorski 2011) — the PiS has heavily relied on anti-German rhetoric in its political discourse and has largely articulated the country's foreign policy identity in opposition to Germany. For the first time since 1989, Germany was downgraded to second among Poland's 'most important European partners' in foreign minister Waszczykowski's 2016 annual Address on foreign policy (Waszczykowski 2016). The first place was, instead, conferred to the UK. Overall, PiS intellectuals, politicians, and ministers castigate Germany as a political and cultural hegemon in Europe, one that encroaches on Poland's sovereignty through its assets in Polish companies and Polish media, that subverts Polish interests through its power in Brussels, and that obstructs PiS transformative conservative agenda (Grajewski 2015; Cichocki 2017). In addition, the PiS government has regularly insisted on-and essentialized-Germany's role as a historical aggressor, notably using the past to represent Poland has a morally superior underdog and to deflect German criticisms on migration or the Rule of Law (Cadier and Szulecki 2020). Not least due to Berlin's economic and structural power in Europe, the PiS government's negative characterization and sometimes outright othering of Germany in domestic political discourse had eventually to be balanced by a more conciliatory posture in its diplomatic interactions with Berlin (see, for instance, Szczerski 2016a). For instance, Germany regained its rank of top European partner in the 2017 Address. Interestingly, according to an analyst who served as advisor to both governments, the PiS government has been waging anti-German rhetoric in public but trying to mend fences through diplomatic channels while the PO government was overly positive about Germany in its political discourse but adopted tough negotiating postures in bilateral backchannels. ${ }^{10}$ Nevertheless, the PiS government's rhetorical practice affected the social fabric of the bilateral relationship, which according to observers has been "weaker than any time since 1989" (Buras and Janning 2018).

Although they had never been as close or as important, relations with France have also deteriorated under the watch of the PiS government. Upon entering office, the latter abruptly cancelled a contract for French armament that had been negotiated by its predecessor. The manner in which this decision was implemented caused unease among French diplomats, which denounced a breach of commercial and diplomatic protocols and complained that their country was "badly treated" in the process. ${ }^{11}$ The PiS foreign policy executive resorted to undiplomatic language and conspiracy theories in relation to this dossier. Referring to a disputed historical anecdote, the Deputy Defence Minister Bartosz Kownacki declared, for instance, on Polish TV that France's annoyance was explained by the fact that "we [Poland] taught these people [the French] to eat with a fork". ${ }^{12}$ It is also in this context that, as mentioned in introduction, the Defence Minister Antoni Macierewicz claimed in Parliament

\footnotetext{
10 Interview with a Polish analyst, 23/05/2019.

11 Interview with a French diplomat, Warsaw, 8 March 2017.

12 The PiS Spokesperson later described this statement as "unfortunate" and "not very diplomatic". 'Poland continues multi-pronged attack on French: "we taught them to use forks", The Guardian, 13 October 2016, https://www.theguardian.com/world/2016/oct/13/poland-continues-multi-pronged-attackon-french-we-taught-them-to-use-forks.
} 
that the French-built Mistral war boats had been surreptitiously channelled to Russia via Egypt, in spite of France's decision to cancel this sale following Moscow's annexation of Crimea. These and other declarations probably often amounted more to uncontrolled rhetoric than to conscious policy, but the fact that they have not been filtered is significant in itself and testifies of the effects of the populist political style on foreign policy making.

While the PiS government de-prioritized the relationships with Germany and France, it sought to invest in alternative partnerships. As evoked, upon entering office, the Szydło government sought to make of the UK Poland's first ally inside the bloc and vowed to consult London "in the first place" on European matters (Waszczykowski 2016). This stance had, however, to be re-evaluated following the UK's decision to leave the EU. Most crucially, the PiS government invested in its relations with other Central and Eastern European (CEE) countries by establishing a new regional framework, the Three Seas Initiative (TSI). President Duda first evoked the idea of creating a "chain stretching from the Baltic Sea [...] all the way to the Black Sea and the Mediterranean Seas" in Tallinn in what was, significantly, his first state visit abroad (Duda 2015). Launched in August 2016 and reuniting 12 EU member states from Central and South-eastern Europe, the TSI essentially consists in a platform meant to develop the infrastructures, inter-connections, and cooperation between the participating states in the fields of energy and transport (Szczerski 2016b). ${ }^{13}$ At the same time, PiS policy-makers have largely regarded the TSI a mean to build a counterweight to Berlin, Paris and Brussels in European affairs (Varga and Buzogány 2020, 13). This latter, unstated objective has, in fact, raised concerns and suspicions among some of Poland's Central European partners, leading them to moderate their support to the initiative and oppose Warsaw's push towards its institutionalization into a permanent secretariat. ${ }^{14}$ Nevertheless, the initiative is interesting in that it tends to contradict traditional expectations regarding populist governments' reluctance towards institutionalized foreign policy cooperation and multilateral organizations (see Introduction).

In sum, the PiS government's has somehow attempted to recalibrate, amend, and diversify Poland's political alliances in Europe, notably by de-prioritizing the partnership with Germany and by attempting to set up an alternative core around the TSI. This markedly contrast with the policies of the PO government-though it should be noted that the latter had itself somehow departed from Polish foreign policy tradition in its over-investment in the bilateral relationship with Berlin-and cannot be correlated with major changes in Europe's balance of power over the period. Rather, it can be elucidated with reference to the use, and influence, of populism as a performative discourse and political style. Essentially, the PiS government has displaced and projected the defining people vs elite dichotomy onto the European scene. The party's foreign policy motto of 'Rising from our knees' clearly echoes the kind of vertical political antagonism characteristic of populist discourse:

\footnotetext{
13 See: Joint Statement on the Three Seas Initiative, Dubrovnik, 25 August 2016, http://three-seas.eu/wpcontent/uploads/2018/06/DUBROVNIK.pdf.

14 Wojciech Przybylski, 'Duda project could trump Visegrad Group', EUobserver, 26 June 2017.
} 
Poland is represented as an 'underdog' that, just as for the people in domestic politics, has been kept down in regional politics and has seen its national demands frustrated by Europe's 'establishment' (i.e. Germany, France, Brussels). These 'elites' of the European system are othered and "totalized through signification" (Laclau 2005b, 39) in PiS policy-makers' discursive practice: Jaroslaw Kaczynski claimed that "in all the important issues Germany [has been] following a policy directed against [Poland's] interests"; FM Czaputowicz has explicitly contrasted France as "the sick man of Europe dragging the continent down" to Poland as its "bright spot"; and the Justice Minister Zbigniew Ziobro has suggested that if Poland "yielded" to EU demands on the party's judicial reforms this would "open the gate" to the imposition of same-sex marriage, abortion on demand, and the euro currency in Poland. ${ }^{15}$ Overall, the populist discourse has been mobilized to advance the party's ideological conservative agenda and tap into long-standing grievances over (undeniable) regional imbalances between East and West in the EU. But by promoting and performatively enacting new representations of Self and Other, these populist discursive practices have structurally constrained and meaningfully informed policy, disabling, for instance, the possibility of a close partnership with Germany and enabling, by contrast, the promotion of the TSI as an alternative core.

\section{Diplomatic practice: performing a rupture with technocratic elites}

The afore-described representations have been channelled through or accompanied by abrasive, disruptive, and uncontrolled comments on the part of the PiS foreign policy executive, comments that break with conventional diplomatic practice and that reflect both the side lining of traditional diplomatic structures and the reliance on populism as a political style.

On the one hand, the 'colonisation' of politico-institutional structures has directly concerned the Ministry of Foreign Affairs and translated into an attempt to marginalize traditional diplomatic elites. The PiS government has reformed the status of Directors and Deputy Directors so that they could be more easily dismissed, has published a nominal list accusing 66 diplomats of having collaborated with the communist regime's secret police to delegitimize them, and has downgraded the role of the MFA in steering the country's foreign policy to the profit of the Presidency and Prime Minister's office. ${ }^{16}$ These measures shed light on the PiS government's general attitude towards foreign policy bureaucracies and evoke parallels with other populists in power, such as Donald Trump (Drezner 2019). At the same time, these measures can hardly be strictly (let alone causally) linked to populism as such, since they also reflect PiS thick ideology (e.g. the long-held view of a collusion between

\footnotetext{
15 'Francja jest chorym człowiekiem Europy', Polsatnews, 17 December 2018, https://www.polsatnews. pl/wiadomosc/2018-12-17/francja-jest-chorym-czlowiek-europy-czaputowicz-o-ataku-w-paryzu-i-prote scie-zoltych-kamizelek/; 'If EU imposes judicial reform on Poland, gay marriage will be next, warns justice minister', Notes from Poland, 30 January 2020, https://notesfrompoland.com/2020/01/30/if-eu-impos es-judicial-reform-on-poland-gay-marriage-will-be-next-warns-justice-minister/.

16 Interview with a Polish diplomat, 17/10/2017.
} 
communist and liberal elites) and proceed at least partly from a reaction to the previous government's political appointments and mode of governance (Bill and Stanley 2020). More specific to populism as a political style though, members of the PiS foreign policy executive have consistently surrounded themselves with advisers from outside established structures of technocratic and diplomatic expertise and, in particular, Foreign Minister Waszczykowski has been described as less open to inhouse expertise than its predecessors. ${ }^{17}$ Interestingly, several of PiS foreign policy advisors or decision-makers are former academics, which tends to run counter the anti-intellectual tendency associated with populism.

On the other hand, the abundance of disruptive and unconventional (or 'undiplomatic') utterances from members of the PiS foreign policy executive also amount to performing a stylistic rupture with traditional elites. Several such comments have been cited throughout this article. Others could be added, such as Defence Minister Macierewicz's conspiratorially equating the 2017 protests against his government's judicial reform to a "hybrid war" waged against Poland from Western Europe or Foreign Minister Waszczykowski's claim that he held diplomatic talks at the UN with the representatives of 'San Escobar', a non-existing country. ${ }^{18}$ All these comments were pronounced by different members of the PiS foreign policy executive, who were kept in ministerial roles for several years. As such, they cannot be simply dismissed as exceptional occurrences attributable to one or two maverick personalities, but testify rather of a reliance on populism as a political style and of its implications in terms of diplomatic practice.

\section{Conclusion}

This article has analysed the contrasts and variations in Polish foreign policy under the PiS government with a view to shed light on the distinctive influence of populism. The impact on Poland's overall foreign policy direction has been limited thus far: geopolitical constrains or incentives remain potent, policies towards Russia and the USA have not been altered, and EU membership is by no means put into question. At the same time, however, significant alterations were noted in Poland's policies in and towards the EU and the effects of populism on foreign policy could paradoxically be more pregnant over the long term.

Rather than as a set of ideas with independent causal effects, populism has been conceptualized here as set of representational practices in domestic politics that spill over, are directly reproduced in, or indirectly affect, foreign policy. It is at the level of foreign policy discourse and diplomatic style that changes have been most salient under the PiS government and it is through these mediums that populism has had

\footnotetext{
17 Interview with a Polish diplomat, Warsaw, 30/10/2017; Interview with a Polish analyst, 23/05/2019.

18 'Poland's president signs controversial law despite protests', The Guardian, 25 July 2017, https:// www.theguardian.com/world/2017/jul/25/polands-president-signs-controversial-law-despite-protests; 'San Escobar: How Poland's foreign minister helped create a fake country', The Washington Post, 11 January 2017, https://www.washingtonpost.com/news/worldviews/wp/2017/01/11/san-escobar-how-polandsforeign-minister-helped-create-a-fake-country/.
} 
an influence on foreign policy outcomes. More specifically, the PiS government's reliance on populist discursive and stylistic practices has led to a securitization of the EU, a partial de-Europeanization of Poland's national interest, a re-shuffling of partnership prioritization in Europe as well as to a number of disruptive, unconventional, and conspiratorial statements ('undiplomatic diplomacy'). By promoting distinct representations so Self and Others and by investing foreign policy as a site to perform a rupture with technocratic elites, the PiS government's has contributed to at least partially re-define the meaning of the EU and of the country's role, identity, and partners in Europe.

In that sense, the influence of populism can be more or less profound in the longterm depending on whether populist actors manage to institutionalize their representations, discourse, and style inside national foreign policy systems and whether nonpopulists come themselves to co-opt or reproduce these practices (as happened in the field of migration-see Schain 2006). For instance, following PiS heavy scapegoating of LGBT groups as threats and Others to the 'pure people', notably through public media and in prevision of the 2019 legislative campaign, a nationwide poll found that Polish citizens were regarding "the LGBT community and gender ideology" as the second biggest threats to the country's security (see: Pacewicz 2019). Similarly, in stark contrast with the 'Return to Europe' narrative that had constituted both an ontological and geopolitical project for Poland and other Central European countries, some of PiS discourse entrepreneur have started to invoke a distinctive 'Eastern' identity for the country (see Cadier and Szulecki 2020). These patterns and their possible long-term implications for foreign policy constitute important and promising venue for future research, just as the theoretical framework advanced in this article would benefit from being applied to other country cases.

Acknowledgment In the course of preparation of this article, the author has received funding from the European Union's Horizon 2020 research and innovation programme under grant agreement no. 769886 (EU-LISTCO project). The article solely reflects the author's views

\section{References}

Balcer Adam, Piotr Buras, Grzegorz Gromadzki, and Eugeniusz Smolar. 2016. Change in Poland, but What Change? Assumptions of Law and Justice Party Foreign Policy. Warsaw: Batory Foundation.

Balcer Adam, Piotr Buras, Grzegorz Gromadzki, and Eugeniusz Smolar. 2017. In a Clinch - The European Policy of the PiS Government. Warsaw: Batory Foundation.

Bill, Stanley, and Ben Stanley. 2020. Whose Poland Is It to Be? PiS and the struggle between Monism and Pluralism. East European Politics 36 (3): 378-394.

Buras Piotr, and Josef Janning. 2018. 'Divided at the Centre: Germany, Poland, and the Troubles of the Trump Era'. London: European Council on Foreign Relations. https://www.ecfr.eu/page/-/divided_ at_the_centre_germany_poland_and_the_troubles_of_the_trump_era.pdf.

Cadier, David. 2019. 'How Populism Spills Over Into Foreign Policy'. Carnegie Europe (blog). 10 January 2019. https://carnegieeurope.eu/strategiceurope/78102.

Cadier, David, and Kacper Szulecki. 2020. Populism, historical discourse and foreign policy: the case of Poland's law and justice government. International Politics 57 (6): 990-1011.

Campbell, David. 1998. Writing Security: United States Foreign Policy and the Politics of Identity. Minneapolis: University of Minnesota Press.

Carlsnaes, Walter. 1993. On analysing the dynamics of foreign policy change: A critique and reconceptualization. Cooperation and Conflict 28 (1): 5-30. 
Chryssogelos, Angelos. 2017. 'Populism in Foreign Policy'. In Oxford Research Encyclopedia of Politics. http://politics.oxfordre.com/view/10.1093/acrefore/9780190228637.001.0001/acrefore-9780190228 637-e-467.

Cichocki, Marek. 2017. 'Niemiecka Skłonność Do Imperializmu Nie Umarła (Interview)'. Fronda.Pl, 26 August 2017. https://www.fronda.pl/a/cichocki-niemiecka-sklonnosc-do-imperializmu-nie-umarl a,98577.html.

Csehi, Robert, and Edit Zgut. 2021. "We Won't Let Brussels Dictate Us": Eurosceptic populism in Hungary and Poland. European Politics and Society 22 (1): 53-68.

Dąbrowska, Ewa. 2018. 'New Conservatism in Poland: The Discourse Coalition around Law and Justice'. In New Conservatives in Russia and East Central Europe, edited by Katharina Bluhm and Mihai Varga, 92-112. Routledge.

Destradi, Sandra, and Johannes Plagemann. 2019. Populism and international relations: (Un) predictability, personalisation, and the reinforcement of existing trends in world politics. Review of International Studies 45 (5): 711-730.

Diez, Thomas. 2014. Setting the limits: discourse and EU foreign policy. Cooperation and Conflict 49 (3): 319-333.

Drezner, Daniel W. 2019. Present at the destruction: The trump administration and the foreign policy bureaucracy. The Journal of Politics 81 (2): 723-730.

Duda, Andrzej. 2015. 'World Peace Impossible without Respect for International Law'. President of the Republic of Poland. https://www.prezydent.pl/en/news/art,18,world-peace-impossible-without-respe ct-for-international-law.html.

Enyedi, Zsolt. 2020. Right-wing authoritarian innovations in central and Eastern Europe. East European Politics 36 (3): 363-377.

George, Alexander L., and Andrew Bennett. 2005. Case Studies and Theory Development in the Social Sciences, 4th ed. Cambridge, Mass: The MIT Press.

Przemysław, Grajewski, and Żurawski Vel. 2015. Poland towards the German leadership in the European union. Confrontation and Cooperation: 1000 Years of Polish-German-Russian Relations 2 (1): 63-84.

Hansen, Lene. 2006. Security as Practice: Discourse Analysis and the Bosnian War. London; New York: Routledge.

Hawkins, Kirk A., Ryan E. Carlin, Levente Littvay, and Cristóbal Rovira. Kaltwasser, eds. 2018. The Ideational Approach to Populism: Concept, Theory, and Analysis. Abingdon, Oxon; New York. NY: Routledge.

Hill, Christopher. 2015. Foreign Policy in the Twenty-First Century. Second Edition. London ; New York, NY: Palgrave Macmillan.

Kazharski, Aliaksei. 2018. The End of "Central Europe"? The Rise of the Radical Right and the Contestation of Identities in Slovakia and the Visegrad Four. Geopolitics 23 (4): 754-780.

Krastev, Ivan, and Stephen Holmes. 2019. The Light that Failed: A Reckoning. Unabridged edition. Penguin Books.

Kuźniar, Roman. 2016. Retreat from the Polish Raison d'Etre or National Interest. Ruch Prawniczy, Ekonomiczny i Socjologiczny 78 (4): 5-16.

Laclau, Ernesto. 2005a. On Populist Reason. London: Verso.

Laclau, Ernesto. 2005b. Populism: What's in a Name? In Populism and the Mirror of Democracy, ed. Francisco Panizza, 32-49. London: Verso.

Lanoszka, Alexander. 2020. Poland in a time of geopolitical flux. Contemporary Politics 26 (4): 458-474.

Larsen, Henrik. 2009. A distinct FPA for Europe? Towards a comprehensive framework for analysing the foreign policy of EU member states. European Journal of International Relations 15 (3): 537-566.

Legutko, Ryszard. 2018. The Demon in Democracy: Totalitarian Temptations in Free Societies. Encounter Books.

Longhurst, Kerry. 2013. Where from, where to? New and old configurations in Poland's foreign and security policy priorities. Communist and Post-Communist Studies 46 (3): 363-372.

Milliken, Jennifer. 1999. The study of discourse in international relations: a critique of research and methods. European Journal of International Relations 5 (2): 225-254.

Ministry of Defense of the Republic of Poland. 2018. 'Proposal for a U.S. Permanent Presence in Poland'. https:/g8fip1kplyr33r3krz5b97d1-wpengine.netdna-ssl.com/wp-content/uploads/2018/05/Proposalfor-a-U.S.-Permanent-Presence-in-Poland-2018.pdf.

Moffitt, Benjamin. 2017. The Global Rise of Populism: Performance, Political Style, and Representation. Stanford, California: Stanford University Press. 
Neumann, Iver B. 2008. Discourse Analysis. In Qualitative Methods in International Relations: A Pluralist Guide, ed. Audie Klotz and Deepa Prakash, 61-77. London, UK: Palgrave Macmillan.

Osica, Olaf. 2004. Poland: A new European Atlanticist at a crossroads? European Security 13 (4): 301-322.

Pew Research Centre. 2016. 'Obama's International Image Remains Strong in Europe and Asia'. 29 June 2016. https://www.pewresearch.org/global/2016/06/29/2-obamas-international-image-remai ns-strong-in-europe-and-asia/.

Plagemann, Johannes, and Sandra Destradi. 2019. Populism and foreign policy: The case of India. Foreign Policy Analysis 15 (2): 283-301.

Pomorska, Karolina. 2012. Poland: Learning the Brussels Game. In National and European Foreign Policies: Towards Europeanization, ed. Reuben Wong and Christopher Hill, 167-188. London: Routledge.

Schain, Martin A. 2006. The extreme-right and immigration policy-making: measuring direct and indirect effects. West European Politics 29 (2): 270-289.

Sikorski, Radosław. 2011. 'Poland and the Future of the European Union, Speech by the Foreign Minister of Poland'.

Stavrakakis, Yannis, and Giorgos Katsambekis. 2014. Left-wing populism in the European Periphery: The case of SYRIZA. Journal of Political Ideologies 19 (2): 119-142.

Sus, Monika. 2018. 'Poland: Leading Critic or Marginalised Hawk?' In EU Member States and Russia: National and European Debates in an Evolving International Environment, edited by Marco Siddi, 77-89. Helsinki: Finnish Institute of International Affairs.

Szczerbiak, Aleks. 2012. Poland Within the European Union: New Awkward Partner or New Heart of Europe? Routledge.

Szczerski, Krzysztof. 2016a. 'Niemcy, nasz pierwszy partner (interview)'. Rzeczpospolita, 10 June 2016. https://www.rp.pl/Swiat/306099888-Szczerski-Niemcy-nasz-pierwszy-partner.html.

Szczerski, Krzysztof. 2016b. 'Trójmorze Nie Jest Alternatywą Dla UE (Interview)'. Rzeczpospolita, 6 September 2016. https://www.rp.pl/Rzecz-o-polityce/160909481-Krzysztof-Szczerski-Trojmorzenie-jest-alternatywa-dla-UE.html?preview $=\&$ remainingPreview $=\&$ grantedBy $=$ preview $\&$.

Taylor, Paul. 2018. 'Poland's Risky “America First” Policy'. POLITICO. 4 October 2018. https://www. politico.eu/article/poland-risky-america-first-policy-jaroslaw-kaczynski-donald-trump/.

Varga, Mihai, and Aron Buzogány. 2020. 'The Foreign Policy of Populists in Power: Contesting Liberalism in Poland and Hungary'. Geopolitics. pp. 1-22.

Verbeek, Bertjan, and Andrej Zaslove. 2015. The Impact of Populist Radical Right Parties on Foreign Policy: the Northern League as a Junior Coalition Partner in the Berlusconi Governments. European Political Science Review 7 (4): 525-546.

Waszczykowski, Witold. 2016. 'Information of the Minister of Foreign Affairs on the Polish Government's Foreign Policy in 2016'. https://www.msz.gov.pl/en/news/minister_witold_waszczykowski_ on_priorities_of_polish_diplomacy.

Wehner, Leslie E, and Cameron G Thies. 2020. 'The Nexus of Populism and Foreign Policy: The Case of Latin America'. International Relations, July, 0047117820944430.

Weldes, J.E., and M. Laffey. 2004. Methodological reflections on discourse analysis. Qualitative Methods 2 (1): 28-30.

Weldes, Jutta. 1999. Constructing National Interests: The United States and the Cuban Missile Crisis. Minneapolis: Unniversity of Minnesota Press.

Wojczewski, Thorsten. 2019a. Populism, Hindu nationalism, and foreign policy in India: The politics of representing "the people." International Studies Review 22 (3): 396-422.

Wojczewski, Thorsten. 2019b. Trump, populism, and American foreign policy. Foreign Policy Analysis 16 (3): 292-311.

Zając, Justyna. 2017. Poland's Security Policy: The West, Russia, and the Changing International Order. London: Palgrave Macmillan.

Zarycki, Tomasz. 2000. Politics in the periphery: political cleavages in Poland interpreted in their historical and international context. Europe-Asia Studies 52 (5): 851-873.

Zięba, Ryszard. 2020. Poland's Foreign and Security Policy: Problems of Compatibility with the Changing International Order. Cham: Springer.

Zielonka, Jan, and Jacques Rupnik. 2020. From revolution to "counter-revolution": democracy in central and Eastern Europe 30 Years On. Europe-Asia Studies 72 (6): 1073-1099.

Zuba, Krzysztof. 2020. 'From the Poster Boy of Europeanization to the Sick Man of Europe: Thirty Years (1990-2019) of Poland's European Policy'. European Politics and Society Online first (June): 1-16. 
Zwolski, Kamil. 2017. Poland's Foreign-Policy Turn. Survival 59 (July): 167-182.

Publisher's Note Springer Nature remains neutral with regard to jurisdictional claims in published maps and institutional affiliations.

David Cadier is Assistant Professor of European Politics in a Global Context at the University of Groningen. He is also an Associate Researcher at LSE IDEAS, the foreign policy think tank of the London School of Economics. His research interests include Foreign Policy Analysis, Central and Eastern Europe, EU-Russia relations, and the foreign policies of populist governments, topics on which he has extensively published. Previously, David Cadier was a Teaching Fellow at the London School of Economics (2012-2015) and a Researcher at Sciences Po's Centre for International Studies (2018-2021). He also held visiting positions at, inter alia, the Fletcher School of Law and Diplomacy, SAIS Johns Hopkins University, the Finnish Institute of International Affairs and the Polish Institute of International Affairs. He obtained his PhD from Sciences Po in 2012. 